\title{
Using Constructive Alignment to Foster Teaching Learning Processes
}

\author{
Preeti Jaiswal ${ }^{1}$ \\ ${ }^{1}$ English Language Centre, University of Bahrain, Kingdom of Bahrain \\ Correspondence: Preeti Jaiswal, English Language Centre, University of Bahrain, Kingdom of Bahrain.
}

\author{
Received: December 15, 2018 Accepted: May 2, 2019 Online Published: May 5, 2019 \\ doi: 10.5539/elt.v12n6p10 URL: https://doi.org/10.5539/elt.v12n6p10
}

\begin{abstract}
This paper delineates the process of constructively aligning course intended learning outcomes, teaching learning activities, and assessment tasks to boost students' accomplishments of intended learning outcomes. It, also highlights, how the usage of two teaching tools, well-regarded by educators, emerged propitious in analyzing students' progression in learning and in augmenting their academic skills. Biggs' model of constructive alignment, Biggs' SOLO taxonomy and Bloom's taxonomy of educational objectives were used for this purpose. Four factors emerged pivotal for efficacy and effectiveness of the process - creating positive learning environments, linking academic content to real life situations, selecting appropriate teaching learning activities and developing learning outcomes that are measurable and attainable, to facilitate the teaching and learning processes.
\end{abstract}

Keywords: constructive alignment, biggs' SOLO taxonomy, learner centered approaches, bloom's taxonomy of educational objectives

\section{Introduction}

In the teacher centred lecture approach, focus is on the teacher transferring knowledge while students learn passively through rote learning and memorization, and emphasis is on the content coverage. This traditional methodology draws a distinction between in class and out of class learning, and focuses on assessing learning by using summative results as the only evidence of learning. However, since 2000, there have been significant changes in the nature of higher education. Not only have the numbers of students enrolled in higher education institutions sharply increased, resulting in higher variance in the students' community but also many other factors have changed the primary mission of higher education institutions as well as the teaching and learning methods in tertiary education.Currently, one objective of higher education institutions is to prepare students to become autonomous learners. In order to accomplish this goal, there must be a paradigm shift from teaching to facilitating effective learning and an understanding of the notion of ownership and 'reflection on learning' as well as the preparedness to take responsibility for not only one's learning but also one's continuous development. Autonomous learning, also called student-centred learning is based on the constructivist theory of learning. Dam (1995) suggests that a gradual move from teacher-centered teaching to a learner-centered class is needed in order to foster learner autonomy in the classroom. Some eminent exponents of constructivist approach include Jerome Bruner, Jean Piaget, Lev Vygotsky, and John Dewey. They are widely perceived in the academia as the preeminent advocates of the constructivism philosophical paradigm (Honebein, 1996). Constructive refers to the concept of learners constructing knowledge through relevant learning activities. Alignment ascribes to the ambiance that educators create, to support active learning activities, for attaining the intended learning outcomes. The essence of this approach, is that all segments - the methodologies, the learning resources, the in class learning activities along with extended learning opportunities that support learning, the curriculum, the intended learning outcomes, as well as the assessment tasks and rubrics for evaluating students' learning - are aligned to each other to facilitate the accomplishment of the intended learning outcomes. Therefore in constructivist approach the relevance is on optimizing active learning opportunities by using student centred approaches and a good functional curriculum design that aligns the teaching learning activities, assessment tasks to intended learning outcomes to measure the level of ILO achieved. Two taxonomies namely Blooms' taxonomy and Biggs' taxonomy are particularly useful in understanding the progression of learning and in describing the structural complexity of students' responses when accomplishing many tasks. Bloom's Taxonomy of educational objectives is a useful tool in ascertaining a learner's level of thinking. Bloom's taxonomy is effective in encouraging higher-order thinking in learners by developing from lower-level cognitive skills. This hierarchical 
taxonomy provides a useful framework in which to categorize test questions when assessing students' learning. Another efficient model of learning is SOLO taxonomy. It assists educators and students in categorizing learning into three levels of knowledge- at surface, deep and conceptual levels and further classifying the learning outcomes or understanding into five hierarchically arranged SOLO levels. This taxonomy gives learners an insight into the level they are in their learning and a medium for gauging their progress in learning.

\section{Material Studied}

It is evident that Constructivist approach has emerged as one of the greatest influences on the practice of education in recent years and educators have been adopting constructivist-based pedagogy eagerly. The prominence given to each learner in the classroom, to the significance of constructing meaning, and to the active participation of learners in the teaching learning process are evidently the very elements that make this Constructivist model agreeable to educators. The formulation of the concept of constructivism is credited to Jean Piaget, who drew attention to the mechanisms by which knowledge is internalized by students. "... all knowledge is tied to action, and knowing an object or an event is to use it by assimilating it to an action scheme..." Piaget, 1967, pp. 14-15). He claimed that through processes of accommodation and assimilation, learners construct new knowledge from their experiences. When learners assimilate, they integrate the new knowledge to pre-existing knowledge. Constructivists propose that "knowledge is not passively received but built up by the cognizing subject" (Von Glasersfeld, 1995). Therefore in the viewpoint of constructivists, the emphasis shifts from viewing knowledge as a commodity to knowing as a procedure, or an activity. The Constructivist pedagogy advocates incorporation of learning activities that are meaningful to learners and which arouse them to reflect and utilize their abilities in taking personal initiatives towards creativity in the learning process. In this pedagogy, activities supplement lectures, and ample opportunities are offered to learners to construct their own understanding on the basis of interaction between what they already know and the new information. Constructive alignment, a prominently employed principle, for formulating teaching and learning activities in higher education, was introduced by John Biggs in 2007. According to Biggs "Constructive alignment is an outcome-based approach to teaching in which the learning outcomes that students are intended to achieve, are defined before teaching takes place". Later he appended that "Teaching and assessment methods are then designed to best achieve those outcomes and to assess the standard at which they have been achieved" (Biggs, 2014). Additionally, Biggs demonstrated that his model is based on the notion that a learner constructs his/her own knowledge through active participation in engaging teaching/ learning activities (Biggs, 2014). Recently, as awareness is increasing, that transmission of knowledge does not result in learning, there is a paradigm shift from the teacher to the learners in the current educational environment. The increasingly popular student centred approaches advocate that knowledge is constructed as a result of learners' active engagement in the learning activities. As learning progresses, it intensifies in complexity. One model that may assist educators and learners in understanding the distinctive levels of growing complexity in the learning process is the Structure of Observed Learning Outcome (SOLO) taxonomy of educational objectives. This taxonomy of Learning objectives which was proposed by Biggs and Collis (1982) is based on the notion that in any 'learning episode, both qualitative and quantitative learning outcomes are influenced by a complex interaction between teaching methodologies and student characteristics' (p. 15). They stressed upon a few factors: the importance of the prior knowledge the student has related to the content, the learners' intrinsic and extrinsic motivation about the learning as well as the learner's learning strategies. The SOLO model or taxonomy of learning makes clear to students and educators alike what the learning outcomes of an activity, module or course programme are. It is a useful tool, for assessing the learning outcomes of students, in terms of their quantity and quality attributes, by classifying learners' responses into anyone of the three levels of knowledge: surface knowledge, deep knowledge conceptual (or constructed) knowledge. According to this cognitive processing taxonomy, a students' learning outcome may further be categorized at one of the five levels of complexity: no idea, one idea, unrelated ideas, connected ideas, extended ideas. Another tool that educators may find useful in designing curriculum or preparing assessments is Bloom's taxonomy. Benjamin Bloom theorized that learning occurs in levels. "Bloom developed a taxonomy for the cognitive domain of learning - a linear progression through knowledge, comprehension, application, analysis, and synthesis to evaluation" (p. 18). Guiding learners to progress through the six hierarchical levels of Bloom's Taxonomy boosts intrinsic motivation and higher order thinking skills and encourages students' autonomy as they think critically and take ownership of their work in all areas of life. The analysis, evaluation, and creation levels relate to knowledge, and educators can adjust learning to encourage students to progress from the lower levels of learning to the higher levels. According to (Richard, 1985), Bloom's taxonomy is arguably one of the most influential works in field of education. Krathwohl (2002, p. 212), claims that Bloom's hierarchical taxonomy is a useful tool for providing a common language about learning goals, to enhance interaction among learners, subject matter, and grade levels; for establishing a basis for a 
particular course or curriculum,or the specific meaning of broad educational goals, like those found in the national, state, and local standards; or as a means for determining the coherence of educational objectives, learning activities, and assessments in a module, course, or curriculum; and for providing an overview of the range of educational possibilities against which the limited scope of any specific educational course or curriculum could be contrasted. The study attempts to answer the following question: Does creating constructive alignment of learning environment as a paradigm significantly enhance learners' achievement of intended learning outcomes?

\section{A) Using Bloom's Taxonomy for Enhancing Learners' Accomplishments through Higher Order Thinking}

The classification of educational objectives in Bloom's Taxonomy serves as a process-oriented model that guides educators to: write measurable students' learning outcomes, structure engaging learning activities, delineate goals for fostering learners' thinking skills and finally assess students' learning. Skill development and development in learning can be categorized into six levels of progressive thought processes: Knowledge (which is exhibited through the recall of facts and information), Comprehension (which is ascertained through the basic understanding of information), Application (which can be evident through the utilization of knowledge and information to tasks), Analysis (which can be measured through successfully dissecting information and understanding of the relation of segments to the whole) Synthesis (which is attainable through the compilation of information into either a new concept or creation), and Evaluation (which is manifested in the ability of making judgments with reference to the worthiness and significance of information) (Ball \& Garton, 2005). The four uppermost levels (Application, Analysis, Synthesis, and Evaluation) are contemplated as higher order thought processes (Bloom et al., 1956; Anderson et al., 2001), and are the commended target for most higher education courses (Ulmer \& Torres, 2007; Ewing, 2006). Bloom's taxonomy guides educators to formulate test questions to determine higher-level thinking skills by outlining test questions as well as assessment prompts that vividly indicate performances required of learners such as recall relevant facts, apply knowledge to do a specific task make a prediction on a given text, solve an issue, evaluate a situation or compose an alternative solution.. The verbs in each category in this taxonomy, illustrate a structured progression of cognitive skills. For instance, lower levels of Bloom's taxonomy verbs display basic thinking skills like memorization of facts. On the contrary, measurable verbs at higher levels characterize complex thinking skills, such as implementing gained knowledge to find practical solutions to issues, analyzing variant interpretations to find the best option, or creating a new idea, pattern or alternative explanation of available findings.

Table 1. Applying bloom's taxonomy for boosting competency

\begin{tabular}{|c|c|c|c|c|}
\hline \multicolumn{2}{|c|}{ Levels of Learning with Description } & \multicolumn{2}{|c|}{$\begin{array}{c}\text { Measurable verbs with Possible } \\
\text { Question stems }\end{array}$} & $\begin{array}{l}\text { Potential Activities } \\
\text { Compose a job } \\
\text { application for an advert. }\end{array}$ \\
\hline Create & $\begin{array}{l}\text { Learners build } \\
\text { segments together to } \\
\text { construct a whole, } \\
\text { with focus on } \\
\text { creating a new } \\
\text { structure. }\end{array}$ & $\begin{array}{l}\text { Generate, } \\
\text { Plan, } \\
\text { Produce, } \\
\text { Compose, } \\
\text { Construct, } \\
\text { Design, } \\
\text { Develop, } \\
\text { Devise, } \\
\text { Design }\end{array}$ & $\begin{array}{l}\text { What do you predict } \\
\text { will be the ending? } \\
\text { Judge } \\
\text { whether..........is } \\
\text { good or bad. } \\
\text { Defend your opinion. } \\
\text { If you were given a } \\
\text { choice how would } \\
\text { you solve } \\
\text { the .....Problem? }\end{array}$ & $\begin{array}{l}\text { Compose a job } \\
\text { application for an advert. } \\
\text { Produce a resume } \\
\text { Create a new report } \\
\text { Plan a proposal for a } \\
\text { business/service in future } \\
\text { Construct a role play } \\
\text { Devise potential } \\
\text { solutions for a given } \\
\text { problem } \\
\text { Design a PPT } \\
\text { presentation }\end{array}$ \\
\hline
\end{tabular}




\begin{tabular}{|c|c|c|c|c|}
\hline \multirow[t]{2}{*}{ Evaluate } & $\begin{array}{l}\text { The ability to judge } \\
\text { the merit of ideas for a } \\
\text { given purpose. }\end{array}$ & $\begin{array}{l}\text { Evaluate, } \\
\text { Recommend, }\end{array}$ & $\begin{array}{l}\text { Which is the best } \\
\text { method to solve this } \\
\text { problem? }\end{array}$ & $\begin{array}{l}\text { Self/peers assess writing } \\
\text { tasks on basis of a set of } \\
\text { criterion. }\end{array}$ \\
\hline & $\begin{array}{l}\text { Learners assess } \\
\text { provided material } \\
\text { using a rubric/criteria } \\
\text { or standard. }\end{array}$ & $\begin{array}{l}\text { Summarize, } \\
\text { Debate, } \\
\text { Criticize, } \\
\text { Judge, } \\
\text { Prioritize }\end{array}$ & $\begin{array}{l}\text { Why would... be } \\
\text { better option? What } \\
\text { do you recommend? }\end{array}$ & $\begin{array}{l}\text { Assemble a portfolio of } \\
\text { writing tasks and } \\
\text { evaluate/reflect on } \\
\text { progress using a rubric } \\
\text { and feedback. } \\
\text { Give group feedback } \\
\text { using guidelines for } \\
\text { student presentations in } \\
\text { class }\end{array}$ \\
\hline Analyze & $\begin{array}{l}\text { The ability to examine } \\
\text { the details of content } \\
\text { material in order to } \\
\text { interpret the } \\
\text { underlying idea. } \\
\text { Learners distinguish } \\
\text { between facts and } \\
\text { inferences. }\end{array}$ & $\begin{array}{l}\text { Analyze, } \\
\text { Distinguish, } \\
\text { Subdivide, } \\
\text { Differentiate, } \\
\text { Examine, } \\
\text { Compare/ } \\
\text { Contrast } \\
\text { Categorize, } \\
\text { Classify }\end{array}$ & $\begin{array}{l}\text { How is this similar } \\
\text { to...? } \\
\text { Examine the effects } \\
\text { of.... } \\
\text { What could have } \\
\text { caused .... }\end{array}$ & $\begin{array}{l}\text { Prepare a report } \\
\text { comparing a present } \\
\text { situation with another } \\
\text { past event? } \\
\text { Review this paragraph in } \\
\text { terms of unity and } \\
\text { structure } \\
\text { Differentiate a coherent } \\
\text { paragraph from an } \\
\text { incoherent one. }\end{array}$ \\
\hline Apply & $\begin{array}{l}\text { The ability to put to } \\
\text { use, taught concepts, } \\
\text { in a new context or } \\
\text { real world experience. } \\
\text { This may entail the } \\
\text { application of rules, } \\
\text { methods learnt in } \\
\text { class. }\end{array}$ & $\begin{array}{l}\text { Apply, } \\
\text { Modify, } \\
\text { Demonstrate, } \\
\text { Implement, } \\
\text { Interpret }\end{array}$ & $\begin{array}{l}\text { Can you apply this } \\
\text { skill in your daily } \\
\text { activities? } \\
\text { How would you } \\
\text { prepare ... by } \\
\text { applying the } \\
\text { strategies you have } \\
\text { studied? } \\
\text { Can you use the } \\
\text { comprehensive list of } \\
\text { writing prompts to } \\
\text { develop a list of } \\
\text { instructions for...? }\end{array}$ & $\begin{array}{l}\text { Use the guidelines to } \\
\text { present an engaging } \\
\text { class presentation. } \\
\text { Refer to sample models } \\
\text { to write an academic } \\
\text { paragraph. } \\
\text { Use behavioral } \\
\text { interviewing strategies to } \\
\text { interview your friend. } \\
\text { Apply experiential based } \\
\text { learning in class to } \\
\text { everyday situations. }\end{array}$ \\
\hline
\end{tabular}




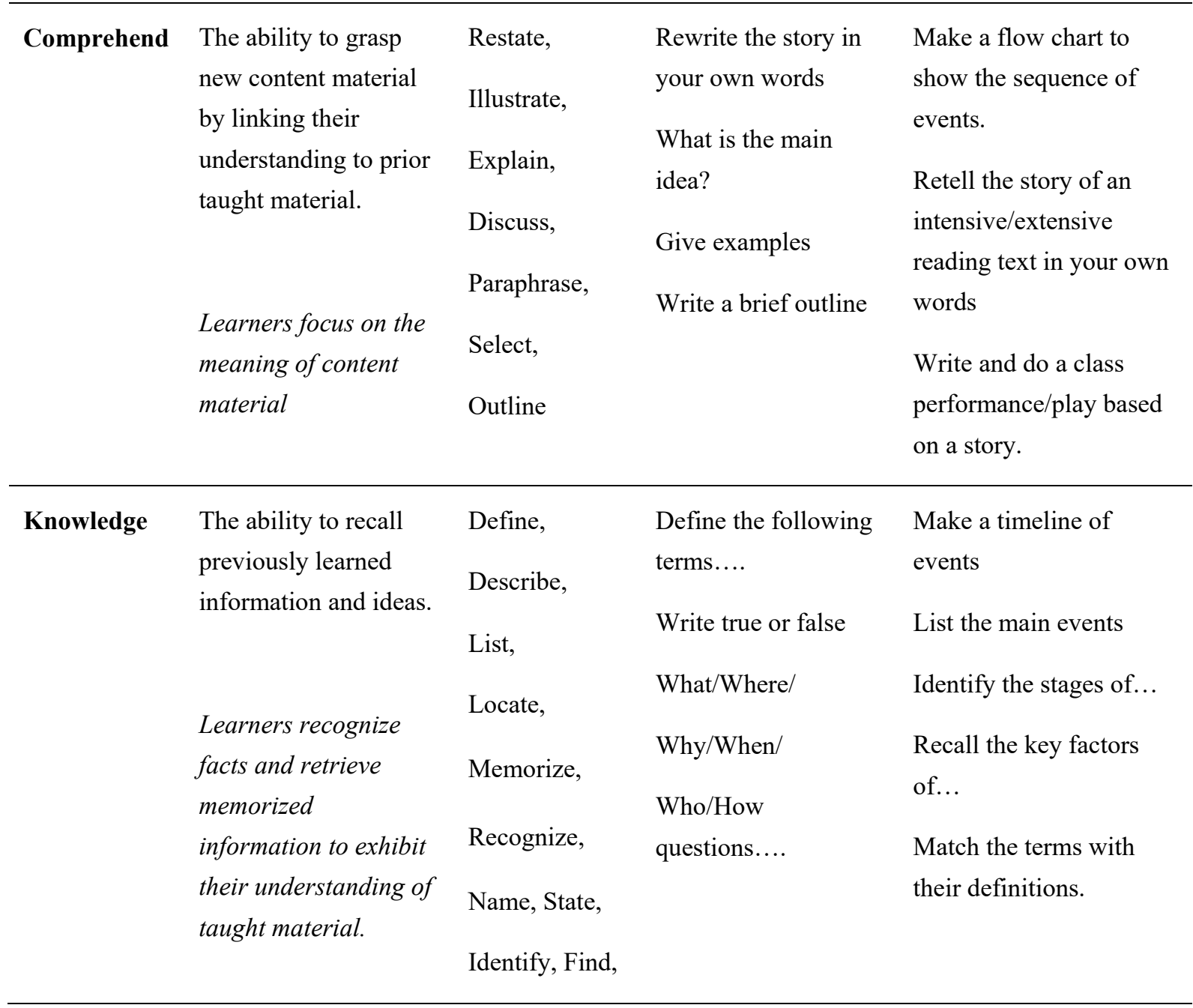

\section{B) Utilizing Biggs' SOLO Taxonomy to Enhance Students' Thinking and Learning}

Structure of Observed Learning Outcomes (SOLO) taxonomy is not a hypothesis about knowledge based on perceptions of educational administrators but a practical model about learning outcomes established on research conducted on student learning (Biggs \& Tang 2007, p. 80). The model categorizes learning outcomes into five stages, which are organized hierarchically, from no knowledge (pre-structural), progressing to surface learning (uni-structural and multi-structural) to developing deep learning (relational and extended abstract). A basic understanding of the structure of SOLO taxonomy assists educators to review students' productions differently do students have the basic knowledge and facts required( indicating accomplishment at surface learning) or are they able to grasp the interconnectedness of the facts/issues before perceiving key concepts thereby (exhibiting deep learning). So, educators can understand the learning process, by reviewing tasks composed by learners in relation to this model. Likewise, it enables learners, to determine their current status regarding their learning accomplishments, and indicates what they must do in order to make headway. Therefore, learners can utilize it to enhance their thinking and learning level. Hattie and Brown propose that SOLO levels assist both learners and educators to comprehend and classify learning experiences as well as learning outcomes according to ascending levels of cognitive complexity (Hattie \& Brown, 2004). At Uni-structural and Multi-structural stages, learners understand one or several aspects of the content. At these levels, understanding is disconnected and at surface level so assessment tasks are primarily quantitative in nature. At the Relational level, learners can link and integrate different aspects of the content and present a more coherent, logically related answer. At this level, understanding is at deep level, so assessment tasks are primarily qualitative in nature. In the highest or extended abstract level, understanding is at a deeper level, and. the previously integrated understanding, may possibly be conceptualized at a higher level of abstraction and generalized to a new topic or area. As at this level, understanding is at a deeper level, so assessment tasks continue to be qualitative in nature. 
Table 2. Categorization of students' learning outcomes according to five SOLO levels of understanding

\section{SOLO LEVELS WITH Learner Attributes at Each Level In Writing Skills Lesson} DESCRIPTORS:

SOLO 1

Prestructural level
Measurable

Verbs
This is the first stage . The learner does not have any knowledge .He does not understand the content, being taught, so is unable to demonstrate understanding. He has missed the point. His responses indicate no recognition of appropriate concept or relevant processing of information. He is yet to grasp the idea and/or needs assistance to grasp the concept.

\section{Delivery of Writing Task}

The task is dealt inappropriately. The work produced has: a poor structure, inconsequential details, poor examples with some misapprehension of the assigned topic, and therefore displays minimal logical relationship with the topic. The response of a prototypal learner at pre-structural stage would likely be 'I don't understand anything'.

\begin{tabular}{|c|c|c|}
\hline & & $\begin{array}{l}\text { Surface knowledge (loose ideas) } \\
\text { Quantitative phase }\end{array}$ \\
\hline $\begin{array}{l}\text { SOLO } 2 \\
\text { Unistructural level }\end{array}$ & $\begin{array}{l}\text { VERBS } \\
\text { Name } \\
\text { Identify } \\
\text { Define } \\
\text { State } \\
\text { Tell } \\
\text { Recall } \\
\text { Recognize } \\
\text { Match } \\
\text { Find }\end{array}$ & $\begin{array}{l}\text { At the second stage, categorized as unistructural, the learner has } \\
\text { limited knowledge. He can understand, one isolated aspect of the } \\
\text { content, being taught. His understanding is disconnected. The learner } \\
\text { is progressing at a basic, preliminary level and has not tackled the task } \\
\text { appropriately. } \\
\text { Delivery of Writing Task: } \\
\text { The work produced has a poor structure. However, the learner can } \\
\text { identify and grasp one single relevant idea related to the topic. The } \\
\text { work focuses largely on this single aspect. This idea is restated in } \\
\text { different ways. The response of a prototypal learner at unistructural } \\
\text { stage would likely be. 'I have some understanding of this topic.' }\end{array}$ \\
\hline $\begin{array}{l}\text { SOLO } 3 \\
\text { Multistructural } \\
\text { level }\end{array}$ & $\begin{array}{l}\text { VERBS } \\
\text { Describe } \\
\text { List } \\
\text { Combine } \\
\text { Classify } \\
\text { Select } \\
\text { Outline }\end{array}$ & $\begin{array}{l}\text { At the next hierarchical stage, classified as Multistructural, the learner } \\
\text { knows a few facts, about the content, being taught. He can understand } \\
\text { two or more aspects of a task, but fails to grasp their relationships to } \\
\text { each other or the whole. At this level, the learner is simply annexing } \\
\text { segments of unconnected information. The performance shows no } \\
\text { organization; therefore, does not make sense to the learner. } \\
\text { Delivery of Writing Task: } \\
\text { The work produced has a poor structure Although the learner selects a } \\
\text { range of material and most selected content is appropriate, but these } \\
\text { ideas are disconnected. The work focuses on a large number of facts } \\
\text { with very little attempt at linking ideas. The response of a prototypal } \\
\text { learner at Multistructural stage would likely be 'I know a few things } \\
\text { about this topic' } \\
\text { Deep knowledge (connected ideas) } \\
\text { Qualitative phase }\end{array}$ \\
\hline $\begin{array}{l}\text { SOLO } 4 \\
\text { Relational level }\end{array}$ & $\begin{array}{l}\text { VERBS } \\
\text { Compare }\end{array}$ & $\begin{array}{l}\text { As learners make headway towards the relational level, the divergent } \\
\text { aspects are linked and integrated, and contribute to a deeper and more } \\
\text { coherent understanding of the composite whole. The whole task has a }\end{array}$ \\
\hline
\end{tabular}




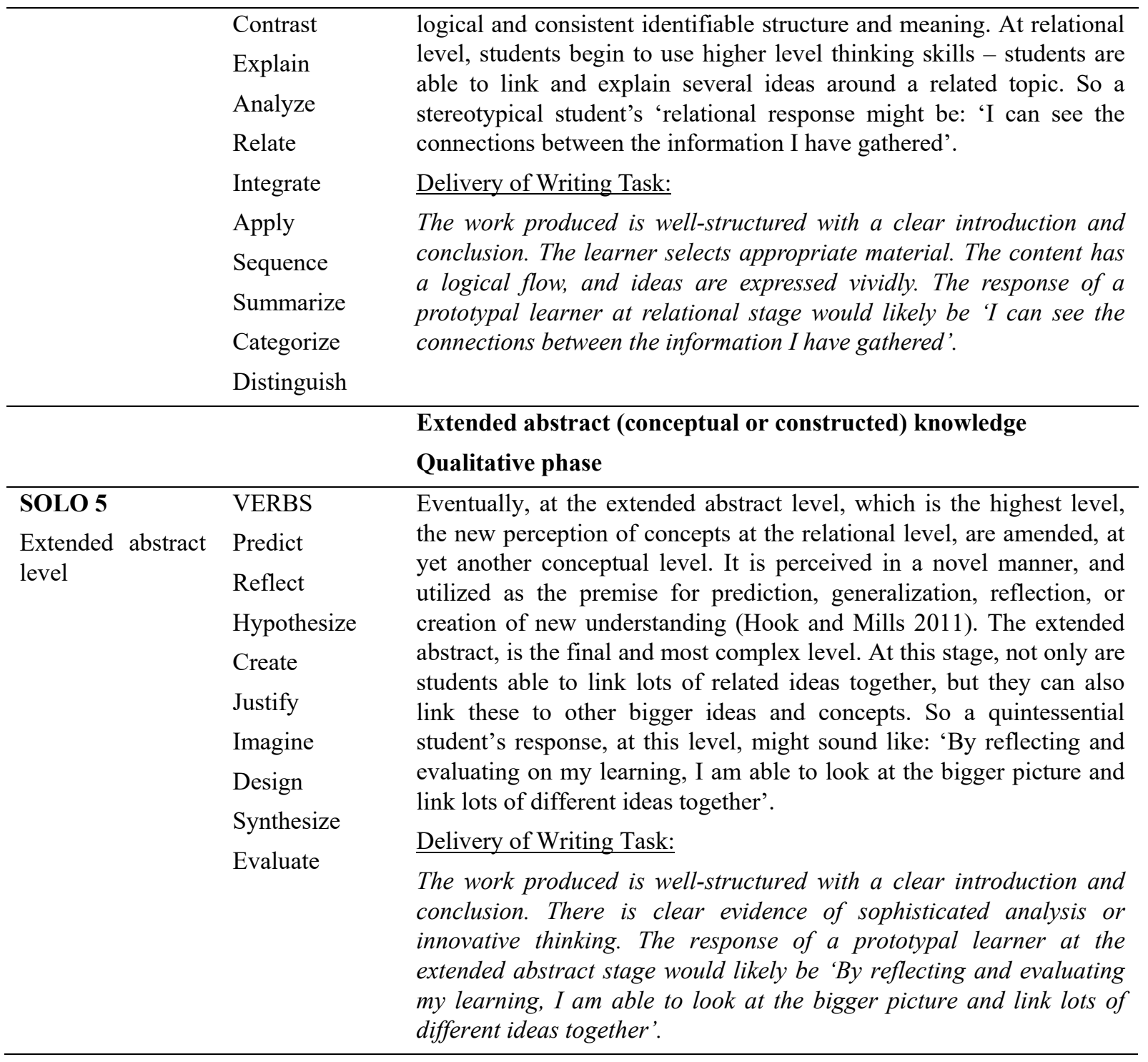

Table 3. A sample of SOLO Task

\begin{tabular}{ll}
\hline SOLO TASK - What causes obesity in children? \\
\hline $\begin{array}{l}\text { SOLO Level of } \\
\text { Understanding: }\end{array}$ & Learner response \\
\hline $\begin{array}{l}\text { SOLO 1 Prestructural } \\
\text { level }\end{array}$ & $\begin{array}{l}\text { Learner beats about the bush, repeats the question stem or is unable to tackle the } \\
\text { question directly. } \\
\end{array}$ \\
& $\begin{array}{l}\text { Many children are obese these days. Obesity is a problem nowadays. Children rush } \\
\text { to the cafeteria during lunch breaks. }\end{array}$ \\
\hline $\begin{array}{l}\text { SOLO 2 Unistructural } \\
\text { level }\end{array}$ & $\begin{array}{l}\text { Only one relevant aspect of the answer is tackled, answer is very opinionated and } \\
\text { entails a limited conclusion. }\end{array}$ \\
& Children are obese because they like fast food too much. \\
\hline $\begin{array}{l}\text { SOLO 3 } \\
\text { Multistructural level }\end{array}$ & $\begin{array}{l}\text { Some aspects of task are addressed but there is no relationship of facts or concepts. } \\
\text { The quality of work does not provide a clear logical structure. }\end{array}$ \\
& $\begin{array}{l}\text { There are fast food restaurants on almost every street and nowadays both parents } \\
\text { are working and social media is addictive. The problem of obesity is increasing. }\end{array}$ \\
\hline SOLO 4 & At relational level, student's performance exhibits higher level thinking. Many \\
\hline
\end{tabular}


Relational level

aspects are interspersed, so that the task has a coherent structure and meaning student is able to link and explain several ideas around a related topic.

So a typical student's 'relational response might be: 'I can see the connections between the ideas I have gathered'. Poor diet can cause obesity. Children gain weight due to lack of physical activities. Also,eating too much of fast food can lead to obesity Sometimes, working parents don't get time to cook, so they give fast, convenience store snacks, or high calorie food to children which consequently makes them fat. Besides, many children are addicted to video games and social media, so they don't burn their calories.

\section{SOLO 5}

Extended abstract level
The final and most complex level is the extended abstract level. At this level, not only is quintessential student, able to link lots of related ideas together, but he/she can also link them to other bigger ideas and concepts.

So a typical student's response at this level might be: 'By reflecting and evaluating on my learning, I am able to look at the bigger picture and link lots of different ideas together'. At this stage, the coherent answer is generalized to a higher level of abstraction. It has a good framework and is well structured. The answer exhibits extensive reading, innovative thinking and sophisticated analysis of the issue. It delineates all the causes of obesity among children and indicates that a research should be carried out in future to identify viable solutions to the problem. It compares the current problem of obesity with the situation ten years ago. It elaborates other related problems, children are facing and elucidates that the solution lies in creating awareness about the effects of behavioral disorders, of the dire need for consuming proper nutrition and of maintaining a healthy lifestyle.

\section{C) Using Constructive Alignment to Burgeon the Learning Process}

"Constructive alignment is a design for teaching in which what it is intended students should learn and how they should express their learning is clearly stated before teaching takes place. Teaching is then designed to engage students in learning activities that optimize their chances of achieving those outcomes, and assessment tasks are designed to enable clear judgments as to how well those outcomes have been attained" (Biggs, 2014, pp. 5-6). Alignment occurs only when the learning activities assigned to learners, engage them in constructing the knowledge intended for the module and are measured by the assessment task. The constructive alignment approach proposes "knowledge is constructed by the activities of the learner" (Biggs, 2014, p. 9) instead of being directly transferred from teacher to student. "Learning takes place through the active behavior of the student: it is what he does that he learns, not what the teacher does." (Tyler, 1949) The basic operational structure underlying constructive alignment involves initially identifying and defining the intended learning outcomes using one verb for each learning outcome. The ILO makes clear at the beginning of the course what learners should be able to perform after the completion of the course. Next, educators create a positive learning environment using interactive teaching/learning activities, (TLAs) that require learners to engage with each verb. TLAs help activate the actionable verbs in ILO. So the verb in the ILO serves as the common element that creates alignment between the ILO, the teaching learning activities, as well as the assessment tasks. Thereafter, educators select the content (units, exercises, supplementary worksheets, online resources) required to support the learning, through in class activities, and extended learning tasks. The topic of the unit serves as the object of this verb. Active engagement in TLA's makes learners develop the skills, knowledge and understandings outlined in the intended learning outcomes. While some ILOs necessitate low level measurable verbs like name, state, describe, list, other ILOs at mediocre level, require specific verbs such as explain, apply, analyze, compare, differentiate to complete a task in connection with a familiar situation whereas ILOs at higher level include verbs like create, generate new alternatives, hypothesize, design, compose to complete open ended tasks in connection with an unfamiliar situation. These actionable verbs reflect various levels of understanding and differ according to each unit. Biggs and Tang (2007) describe ILOs as "statements, written from the students' perspective, indicating the level of understanding and performance they are expected to achieve as a result of engaging in the teaching and learning experience" (p. 55). Later, educators use those specific verbs while preparing assessment tasks in order to figure out how competently learners' have accomplished the intended learning outcomes. Finally, educators may transform their judgments into summative grades by using standards-based grading system. The final grading data may be transformed quantitatively or qualitatively. For Quantitative scoring, information is collected 
numerically as percentages and graded according to a scale. For example 90 marks $=$ grade A. In the other alternative, grading of learners' accomplishments is done qualitatively, by using a rubric, consisting of descriptors for high, medium or low achievements. In this way, learners' answers to a set of question stems or a specific academic skill such as reading comprehension skills may be analyzed. In this type of scoring, focus is on a holistic judgment instead of numerical scores. In most cases, educators may find that final grades consisting of a blend of both quantitative and qualitative data are useful in gaining a complete analysis of learners' performances in order to determine their areas of strengths and weaknesses. The aligned system emphasizes on the significance of linking learning concepts to learners' prior knowledge and real life experiences and enables learners to understand the relevance of learning by making them understand its utility in future workforce environment through reflection. SOLO model also emphasizes on students' motivation and engagement while learning; as well as students' learning strategies. Some useful instructional strategies for tapping into learners'prior knowledge include incorporating KWL teaching model (Ogle, 1986) ( what I know-What I want to learn-How can I learn this-What I learnt), or using if/then statements so learners can make connections between new and previously taught materials and/or with relevant life experiences. Some other learning activities that facilitate active engagement in class include using the jigsaw puzzles, think-pair-share activities, and incorporating experiential learning activities and work readiness skills within curriculum. Linking the academic content to real life situations encourages students to make connections between their current learning and their utility and relevance to their future career paths. It encourages the big picture perspective. It boosts their intrinsic and extrinsic motivation levels, promotes complete engagement in learning activities and paves the way for higher accomplishments of intended learning outcomes.

Table 4. Implementation of constructive alignment (sample 1) intended learning outcomes for a writing course

\section{On completion of this course, students should be able to:}

- $\quad$ Exhibit basic knowledge of previously learned material by recalling terms and basic concepts.

- Demonstrate factual and practical knowledge of course content by organizing, comparing, interpreting, giving descriptions, stating main ideas and looking for details.

- Apply acquired knowledge, facts, techniques, and rules to known practical contexts, by planning how skills will be used to address set situations and adapting as necessary.

- Analyze and Evaluate information by drawing connections among ideas, comparing contrasting; making inferences and finding evidence to support generalizations, drawing conclusions, and suggesting solutions.

- Create independently a variety of business communication materials such as emails, and business letters in both familiar and unfamiliar situations using academic writing style. 
Table 5. Implementation of constructive alignment (sample 2) aligning teaching for constructing learning by applying Bloom's Taxonomy to encourage higher-order thinking

\begin{tabular}{|c|c|c|c|c|}
\hline \multicolumn{2}{|c|}{ Intended Learning Outcome with Methodology } & \multicolumn{2}{|c|}{ Action verbs and Activities } & $\begin{array}{l}\text { Assessment Task } \\
\text { Compose a job } \\
\text { application letter } \\
\text { for an authentic }\end{array}$ \\
\hline $\begin{array}{l}\text { Create } \\
\text { independently a } \\
\text { variety of business } \\
\text { communication } \\
\text { materials such as } \\
\text { emails, and } \\
\text { business letters in } \\
\text { both familiar and } \\
\text { unfamiliar } \\
\text { situations using } \\
\text { academic writing } \\
\text { style. }\end{array}$ & $\begin{array}{l}\text { Incorporated all levels of Bloom's } \\
\text { taxonomy to achieve intended } \\
\text { learning outcome. Why? } \\
\text { - To promote higher-order } \\
\text { thinking skills by developing } \\
\text { lower-level cognitive skills. } \\
\text { - To bridge the gap between } \\
\text { knowledge and application. } \\
\text { - To apply experiential } \\
\text { learning to workplace situations }\end{array}$ & Understand & $\begin{array}{l}\text { Construct formal } \\
\text { letters } \\
\text { Summarize key } \\
\text { elements for writing } \\
\text { business letters. } \\
\text { Differentiate good, } \\
\text { mediocre and poor } \\
\text { samples of business } \\
\text { letter.(self/peer } \\
\text { review) } \\
\text { Apply guidelines to } \\
\text { write a formal letter } \\
\text { of enquiry. } \\
\text { Identify differences } \\
\text { between a formal } \\
\text { email and business } \\
\text { letter } \\
\text { Recall layout and } \\
\text { cohesion, coherence } \\
\text { strategies for writing } \\
\text { a formal email. }\end{array}$ & $\begin{array}{l}\text { Compose a job } \\
\text { application letter } \\
\text { for an authentic } \\
\text { job advert } \\
\text { - The assessment } \\
\text { task measured the } \\
\text { attainment of } \\
\text { intended learning } \\
\text { outcomes of a } \\
\text { writing skills } \\
\text { course. } \\
\text { - Used rubric as } \\
\text { evaluation } \\
\text { checklist to } \\
\text { identify strengths } \\
\text { and weaknesses } \\
\text { of learner } \\
\text { performances. }\end{array}$ \\
\hline
\end{tabular}

\section{Method}

The study utilized quantitative method to analyze if there was a statistically significant difference between learners' performances in the test before and after constructively aligning learning environment and applying Bigg's SOLO taxonomy and Blooms' taxonomy to enhance learners' proficiency levels and accomplishments of intended learning outcomes.

\subsection{Sample}

The sample comprised of 30 students (fifteen males and fifteen females) who were studying the course titled Language Development (Level two) of the Associate Diploma in Office Management Program in the English Language Centre, University of Bahrain, during the academic year 2018-19. Language Development (Level two) is a credit bearing course which develops learners' English language skills with emphasis on academic and business writing skills, so that they can competently produce a variety of business-related correspondences.

\subsection{Instrument}

Pre- and post-tests were used to collect data in order to examine learners' progression of academic skills. Additionally, learners attainments of learning tasks during in class activities were observed, as well as learners' opinions were converged through discussions. The test consisted of multiple-choice questions, cloze questions, defining content words, sentence completions, locating pronoun references, determining the meaning of words and phrases from the given alternatives of domain specific vocabulary, finding main idea and supporting details, using text structure to comprehend the meaning from context, and composing academic paragraph and formal email. The assessment analyzed learners' competency in language skills by gauging their performance levels in the tests. Pre- and post- tests were obtained from students and scores were entered into SPSS. A paired sample t-test was used to investigate if there is a significant difference between learners' achievement on the pretest and post-test scores after the intervention.

\section{Result}

According to the evaluation analysis of quantitative data, the results showed that aligning the curriculum design for constructing learning along with applying the educational objectives in Bloom's Taxonomy and Biggs' SOLO organizational taxonomy had a statistically significant positive impact on the academic achievement of 
learners as the student centred approaches enhanced learners' proficiency in achieving the intended learning outcomes, $t(29)=3.94, p<0.05$. The evaluation likewise displays that all cognitive domains of Bloom's taxonomy are significant and are applicable in classroom activities to foster active participation of students. The findings also reveal that although the most significant cognitive domains in Bloom's taxonomy are creation, evaluation and knowledge; but the most applicable are remember, understand, analyze and apply as a lot of emphasis is allocated to remembering and recalling the knowledge. The findings of this study further display that educators should build a positive learning environment for active learning to happen by incorporating student centred activities like discussions, brain storming sessions, encouraging text think aloud questions, asking open ended questions, encouraging elaboration of texts, using logical reasoning in problem-solving strategies, clarifying, implementing experiential learning activities, previewing structure, role playing, incorporating students' presentations, promoting self /peer review of learning tasks, using gamification, facilitating collaborative and cooperative learning activities, as these kinds of instructional strategies boost opportunities for students to attain ILOS. According to (Thomas, 2007) teachers "need to build a community in which students experience their passion" A positive environment creates optimal learning opportunities for each student to attain ILOS. Student centred approaches are useful in developing an environment supportive of learning with a focus on the learner's experience; offering a variety of teaching and student activities (Kember, 2009); emphasizing creativity and discovery (Ewell, 2007), active rather than passive learning (Lea et al., 2003) and developing holistic not fragmented understanding. A study by Smith (1977) revealed that three types of classroom interactions: positive interactions between students and instructors, the frequency and cognitive level of student participation, and peer-to-peer interactions among students in a course consistently and positively related to 31 critical thinking skills (Tsui, 2002). There are many other ways of encouraging appropriate learning activities (Chapter 5, Biggs 2003), even in large classes (Chapter 6). Students' involvement with active learning generates high quality learning. Assignments and in-class discussions offer students the opportunities to develop higher cognitive skills in a self-motivated environment. Research findings also indicated that incorporating cooperative learning into assessments by encouraging interactions through assignments or in a cooperative peer-to peer learning situation boost development of critical thinking skills (Tsui, 2001; 1999; Astin, 1993). The findings of this study further suggested that instructors should ask higher levels questions. According to Lingard et al. (2001), higher order thinking "occurs when students manipulate information and ideas in ways which transform their meaning and applications" (p. 18). These variant levels of cognitive behavior display progressively complex skills in a hierarchical order (Webb, 1970). Consequently, students must attain (lower level skills) like understand and comprehend and use higher level skills to formulate the knowledge in composition or creation of some new method (higher order).

\section{Discussion}

Constructive alignment is the underpinning concept for criterion based assessment as the model displays an aligned design for outcome based teaching. It is useful,both, in coping with mixed-ability classes with learner differences in terms of learning styles, motivation levels, attitudes, beliefs and differences of previous educational experiences and accomplishments as well as in constructively aligning learning outcomes with learning activities and assessment tasks. The assessment tasks, consist of outcome statements involving a learning activity, a measurable and attainable verb, that learners need to perform to best achieve the outcome, such as "apply the five step process to develop an academic paragraph," or "explain the components of a resume" The measurable verb, i.e "create a job application letter for an authentic job advert" illustrates a suitable learning activity for students to perform in order to attain the intended learning outcome in the course design. Learning is constructed by what activities the learners perform-while engaging in hands-on tasks. Learning therefore is about what students do, not about what educators do. Likewise, assessment tasks display, not how well learners are able to report back to educators what they have memorized, but how competently students have accomplished the intended outcomes. Biggs and Collis (1982) claim that their model is the 'only instrument available for assessing quality retrospectively in an objective and systemic way that is easily understandable by both teacher and student.' (p. xi). High quality learning outcomes are associated with deep approaches, whereas low quality outcomes are associated with surface ones (Biggs, 1987; Entwistle, 1988; Harper \& Kember, 1989; Marton \& Säljö, 1984). At the extended abstract level, the new notion is observed in an innovative manner, and applied as hypothesis for prediction, generalization, reflection, or creation of new understanding (Hook \& Mills 2011)

\section{Conclusion}

Constructive alignment is a useful model for formulating teaching learning activities and assessment tasks that directly address the intended learning outcomes in a manner not typically accomplished in traditional lectures. 
While learning outcomes outline what learners should be able to do, assessment criteria demonstrate how well learners should be able to perform it. Ramsden (1992) states that for the learner the assessment is the curriculum. Learners learn what they believe they are likely to be assessed on, rather than all content in the curriculum. One way of tackling this is by ensuring that the assessment tasks mirror the ILOs. If the curriculum is reflected in the assessment, then the teaching activities of the educators and the learning activities of the learner focus on the same goal. Hence, while doing preparations for the assessments, learners will in fact be studying the subject information. It is suggested that learning outcomes should be clearly visible in course outline, and learners should know the ILOS at the beginning of any course. It is pivotal to write clear and constructively aligned learning outcomes that indicate what a learner is expected to accomplish at the end of a program of study, as well as what standard or level of achievement is anticipated and how they are expected to demonstrate their learning. It is suggested that learning outcomes be comprehensible, specific, measurable, and attainable, so learners are able to accomplish ILOs with appropriate efforts. Also, learning outcomes must be relevant to learners' goals and future careers. One may prefer to use Blooms' taxonomy, in selecting action words in ILOs for aligning curriculum design, as it provides a very operational approach for classifying test questions when assessing students' learning by listing measurable verbs to describe and classify observable knowledge and skills at all six hierarchical levels. This enables educators to easily phrase questions for all cognitive levels and augment students' higher thinking levels by assigning questions that initially demand simple, basic thinking skills and eventually bloom into complex questions demanding engagement with questions through inference, reasoning, evaluating, and composing, demonstrating deeper cognitive learning and skill (Barr \& Tagg, 1995). Hence, Bloom's Taxonomy can be a very powerful tool in assisting students to learn at higher and more critical levels. On the other hand, SOLO Taxonomy is effective in outlining different levels of understanding built into intended learning outcomes, as well as in creating rubrics or criteria of assessment. Educators may also find SOLO taxonomy very applicable and convenient in depicting students' learning experiences and their assessments, and in further outlining the follow-up learning experiences at appropriate levels of cognitive complexities with the aim of challenging rather than overwhelming learners. The structural framework of this taxonomy proves favorable in preparing questions at one level of cognitive complexity and at the same time ascertaining different levels of cognitive complexities in student's answers within that level. For instance, while assessing a students' learning outcome the verb - 'compare' can be used at Unistructural, Multistructural, relational or extended abstract levels. SOLO provides a lot of clarity while writing a course ILOs. For example, measurable verbs such as demonstrate, discuss, explain classify, report, interpret, paraphrase, predict compare, exemplify, conclude, identify, and illustrate demonstrate learners' competency at the 'understanding' category in Blooms' taxonomy (Anderson and Krathwohl 2001). Furthermore, SOLO taxonomy characterizes these measurable verbs, from one generic category ,as given in Bloom's taxonomy, to three distinct levels of learning outcomes, facilitating not only greater clarity when assisting students' learning but also assisting in formulating more specific ILO's (Biggs $\&$ Tang 2007, p. 80). Interestingly, the categories in both taxonomies are not content specific and can be applied to any experience that involves learning, and shifts in levels of understanding.

\section{Limitations of the Study}

This study is limited by the relatively small sample size used for the purpose. Thirty students studying the course titled Language Development (Level two) of the Associate Diploma in Office Management Program in the English Language Centre, University of Bahrain, participated in this study during the academic year 2018-19.

\section{Recommendation}

Based on the findings, this study recommends that student centred approaches such as the model of Constructive alignment and Blooms' taxonomy and Biggs' SOLO taxonomy are useful in enhancing teaching learning processes and in developing learners' competencies. Constructive alignment provides a framework that displays an aligned design for outcome based teaching. And both taxonomies are effective for educators in explaining to students, their progress in learning, by categorizing their learning outcomes from simple to complex levels. While applying Bloom's taxonomy, educators would look for the relationship between the task questions asked and learners' responses obtained; on the other hand while using SOLO taxonomy educators may prepare questions for different levels of complexity as well as categorize learners' responses according to whether the learner has only basic knowledge and facts required, indicating learning at surface level,or if they can recognize the relationships of the facts/issues and understand the essence of the content demonstrating deep learning. This framework is comprehensive and classified into distinct levels which may be applied to different subjects as well as a variety of assignments (Hattie \& Purdie, 1998). 


\section{References}

Astin, A. W. (1993). What matters in college? Liberal Education, 79(4), 4-15.

Anderson, L. W., Krathwohl, D. R., Airasian, P. W., Cruikshank, K. A., Mayer, R. E., Pintrich, P. R., ... Wittrock, M. C. (2001). A Taxonomy for Learning, Teaching, and Assessing: A revision of Bloom's Taxonomy of Educational Objectives. New York: Pearson, Allyn \& Bacon.

Ball, A. L., \& Garton, B. L. (2005). Modeling higher order thinking in teacher preparation: Relationships between objectives, classroom discourse, and assessments. Journal of Agricultural Education, 46(2), 59-69. https://doi.org/10.5032/jae.2005.02058

Barr, R. B., \& Tagg, J. (1995). From Teaching to Learning: A New Paradigm for Undergraduate Education. Journal of Change, Research Library Core, 12. https://doi.org/10.1080/00091383.1995.10544672

Biggs, J. B., \& Collis, K. (1982). Evaluating the Quality of Learning: the SOLO taxonomy. New York, Academic Press

Biggs, J. B. (1987). Student approaches to learning and studying. Melbourne: Australian Council for Educational Research.

Biggs, J. B. (2003). Teaching for quality learning at university. Buckingham: Open University Press/Society for Research into Higher Education.

Biggs, J., \& Tang, C. (2007). Teaching for quality learning at university. What the student does. Berkshire: Society for Research into Higher Education \& Open University Press.

Biggs, J. (2014). Constructive alignment in university teaching. HERDSA Review of Higher Education, 1, 5-22.

Bloom, B. S., Engelhart, M. D., Furst, E. J., Hill, W. H., \& Krathwohl, D. R. (1956). Taxonomy of educational objectives: The classification of educational goals, by a committee of college and university examiners. Handbook 1: Cognitive domain. New York: Longmans.

Bloom's Taxomony Action Verbs. Retrieved from http:/www.clemson.edu/assessment/assessmentpractices/ referencematerials/documents/Blooms\%20Taxonomy\%20Action\%20Verbs.pdf

Dam, L. (1995). Learner Autonomy 3: From Theory to Classroom Practice. Dublin: Authentik.

Entwistle, N. J., \& Kozeki. (1988). Dimensions of motivation and approaches to laerning in Eintish and Hungarian secondary schools. International Journal of Educational Research. https://doi.org/10.1016/ 0883-0355(88)90003-1

Ewell, P. (2007). The "Quality Game": External Review and Institutional Reaction over Three Decades in the United States. In D. Westerheijden, B. Stensaker, \& M. Rosa (Eds.), Quality Assurance In Higher Education. Springer Netherlands, Dordrecht. https://doi.org/10.1007/978-1-4020-6012-0_5

Ewing, J. C. (2006). Teaching techniques and cognitive level of discourse, questions, and course objectives, and their relationship to student cognition in College of Agriculture class sessions. (Doctoral Dissertation).

Harper, G., \& Kember, D. (1989). Interpretation of factor analyses from the Approaches to Studying Inventory. British Journal of Educational Psychology, 59(1), 66-74. https://doi.org/10.1111/j.2044-8279.1989. tb03077.x

Hattie, J., \& Purdie, N. (1998). The SOLO model: Addressing fundamental measurement issues. In B. Dart, \& G. Boulton-Lewis (Eds.), Teaching and Learning in Higher Education (pp. 145-176). Acer Press.

Hattie, J. A. C., \& Brown, G. T. L. (2004, September). Cognitive processes in asTTle: The SOLO Taxonomy. asTTle Tech. Rep. \#43, University of Auckland/Ministry of Education.

Hook, P., \& Mills, J. (2011). SOLO Taxonomy: A guide for schools - A common language for learning Book 1 Essential Resources Educational Publishers NZ

Honebein, P. C. (1996). Seven goals for the design of constructivist learning environments. In G. W. Brent (Ed.). Constructivist learning environments: case studies in instructional design. Educational Technology Publications. New Jersey: Englewood Cliffs

Kember, D. (2009). Promoting Student-Centered Forms of Learning across an Entire University. Higher Education, 58, 1-13. https://doi.org/10.1007/s10734-008-9177-6

Krathwohl, D. R. (2002). A revision of Bloom's taxonomy: An overview. Theory into practice, 41(4), 212-218. https://doi.org/10.1207/s15430421tip4104_2 
Lea, S. J., Stephenson, D., \& Troy, J. (2003). Higher Education Students' Attitudes to Student-centered Learning: Beyond 'educational bulimia'. Studies in Higher Education 28(3), 321-334. https://doi.org/10.1080/ 03075070309293

Lingard, B., Ladwig, J., Mills, M., Bahr, M., Chant, D., \& Warry, M. (2001). The Queensland school reform longitudinal study. Brisbane: The State of Queensland (Department of Education).

Marton, F., \& Saljo, R. (1984). Approaches.to learning. In F. Marton, D. J. Hounsell, \& N. J. Entwistle (Eds.), The experience of learning (pp. 36- 55). Edinburgh: Scottish Academic Press.

Ogle, D. (1986). K-W-L: A teaching model that develops active reading of expository text. The Reading Teacher, 39, 564-570. https://doi.org/10.1598/RT.39.6.11

Piaget, J. (1967). Biologie et connaissance (Biology and knowledge). Paris, Gallimard.

Ramsden, P. (1992). Learning to teach in higher education. London: Routledge. https://doi.org/10.4324/9780203413937_chapter_8

Richard, P. (1985). Bloom's taxonomy and critical thinking instruction. Educational Leadership, 42(8), 36-39.

Smith, D. G. (1977). College classroom interactions and critical thinking. Journal of Educational Psychology, 69, 180-190. https://doi.org/10.1037/0022-0663.69.2.180

Thomas, J. (2007). Teaching with passion. Education Digest: Essential Readings Condensed for Quick Review, 73(3), 63-65.

Tsui, L. (1999). Courses and instruction affecting critical thinking. Research in Higher Education, 40, 185-200. https://doi.org/10.1023/A:1018734630124

Tsui, L. (2000). Effects of campus culture on students' critical thinking. Review of Higher Education, 23, 421-441. https://doi.org/10.1353/rhe.2000.0020

Tsui, L. (2001). Faculty attitudes and the development of students' critical thinking. Journal of General Education, 50, 1-28. https://doi.org/10.1353/jge.2001.0008

Tsui, L. (2002). Fostering critical thinking through effective pedagogy: Evidence from four institutional case studies. Journal of Higher Education, 73(6), 740-763. https://doi.org/10.1353/jhe.2002.0056

Tyler, R. W. (1949). Basic principles of curriculum and instruction. Chicago: University of Chicago Press.

Webb, J. N. (1970). The Florida taxonomy of cognitive behavior. In A. Simon, \& E.G. Boyer, (Eds.), Mirrors for behavior: An anthology of classroom observation instruments.

Ulmer, J. D., \& Torres, R. M. (2007). A classroom assessment of agricultural teachers' cognitive behaviors. In G. E. Briers, \& T. G. Roberts (Eds.). 2007 AAAE Research Conference: 43, Minneapolis, MN.

VonGlasersfeld, E. (1995). A constructivist approach to teaching. In L. P. Steffe, \& J. Gale (Eds.), Constructivism in education (pp. 3-15). Hillsdale, NJ: Lawrence Erlbaum Associates.

\section{Copyrights}

Copyright for this article is retained by the author(s), with first publication rights granted to the journal.

This is an open-access article distributed under the terms and conditions of the Creative Commons Attribution license (http://creativecommons.org/licenses/by/4.0/). 